\title{
Famine Oedema
}

\author{
By J. BEATtie and PHilipPa H. HeRberT (Leverhulme Scholar) \\ Bernhard Baron Research Laboratories, Royal College of Surgeons of England, \\ Lincoln's Inn Fields, London, W.C. 2
}

AND D. J. BELL, Biochemical Laboratory, University of Cambridge

(Received I5 Fannary 1948)

This study of nutritional or famine oedema was carried out on twenty-seven patients admitted to two hospitals in Holland in April, May and June 1945, and on eleven inmates of a civil prison in the British Zone of Germany during the summer of 1946. The latter individuals were not hospital patients, and were engaged in either light or moderate physical work in the prison until they were selected as suitable subjects for study. After selection they were allowed out of bed during the day, but were not permitted to leave their cells except for $30 \mathrm{~min}$. of outdoor exercise (walking in the prison yard) each day. The Dutch group contained individuals of both sexes aged between 21 and 77 years. The German group was made up of ten males between the ages of 21 and 31 years and one male aged 52 years. Because of their reduced food intake, both Dutch and German subjects had suffered considerable weight loss. They showed no clinical sign of organic disease.

The first phase of the investigation was devoted to a clinical study of the cases in hospital while under various dietetic regimes, and to the determination of the plasmaor serum-protein concentrations. At our request Dr John F. Loutit carried out a series of determinations of plasma volumes on some of the Dutch group. Towards the end of the first phase it became clear that more attention had to be paid to the state of hydration of the individuals, but by then famine oedema had disappeared from the Dutch civilian population. In the later work in Germany more attention was paid to the plasma and extracellular fluid volumes and to the changes in such volumes which occurred under controlled dietetic conditions.

When the data from the above sources were analysed, they were discussed with Dr Ancel Keys and his colleagues in Minneapolis who had carried out a large-scale experiment on the effects of prolonged undernutrition. The two sets of data were found to be complementary and, as the Minneapolis material was at that time ready for publication (Henschel, Mickelsen, Taylor \& Keys, 1947), it was agreed that our data would be arranged in such a way as to permit comparison with these data. This arrangement was of importance, as our study was made on subjects who had reached the end of a long period of semi-starvation but for whom no reliable information, other than their normal bedy-weights, was available concerning their normal state. 


\section{METHODS}

\section{Diets}

The dietary history of the Dutch group prior to admission to hospital was fragmentary except for seven individuals who were patients over the period December 1944-April 1945. The dietary history of the German group before it came under observation was estimated roughly by examination of the daily records of food issued to the kitchen department of the prison over the period July 1945-June 1946. The dietary history of most of the Dutch group during their stay in hospital was known with accuracy, as these patients were being studied in nitrogen balance experiments. The daily intake, however, varied very widely, ranging from an initial low intake of $1172 \mathrm{Cal}$./day to a high intake of $3518 \mathrm{Cal}$./day. In the German group, the initial period of observation consisted of 28 days during which a constant intake of $1700-1750 \mathrm{Cal}$./day was maintained, as this level was that on which the subjects had existed for some months. This intake was raised in steps at intervals of 10, 15 , ro and ro days. The final diet period lasted 13 days, during which the calorie intake was $2530 \mathrm{Cal}$./day (Beattie, Herbert \& Bell, 1947, Table I).

\section{Plasma- or serum-protein concentration}

Routine determinations of the total plasma- or serum-protein concentrations were carried out by the specific gravity method described by Phillips, Van Slyke, Dole, Emerson, Hamilton \& Archibald (1945), or by the specific gravity 'gradient' method of Jacobsen \& Linderstrøm-Lang (1940). The accuracy of these determinations was checked periodically by determining the total and non-protein nitrogen of the plasma and serum samples by a semi-micro-Kjeldahl method. Protein was expressed as nitrogen $\times 6.25$. 'The 'albumin' protein plus non-protein nitrogen of the plasma or serum proteins was determined after precipitation of the globulin plus fibrinogen in the plasma samples and of the globulin in the serum samples. The globulins plus fibrinogen were precipitated by the method of Greenberg (1929). No separate estimation of the fibrinogen content of plasma was made.

Blood samples were collected from all subjects in the morning before breakfast and under basal conditions. In taking the samples blood was withdrawn from an arm vein without stasis. Heparin was the anticoagulant used to obtain plasma samples.

\section{Plasma volume}

Plasma volumes were estimated by the dye-dilution method of Gibson \& Evans (1937) and Gibson \& Evelyn (1938) using the dye Ti824. The dye (10 mg.) was injected in $10 \mathrm{ml}$. of $0.9 \% \mathrm{NaCl}$ solution. To secure uniformity of the dye solution, quantities of $\mathrm{I} 1$. were prepared and, after sterilization, sterile glass ampoules were filled with $10.5 \mathrm{ml}$. of solution. The concentration of the dye in several of the ampoules was estimated and, if necessary, a correction factor applied in any subsequent calculations. Calibrated syringes to deliver $10 \mathrm{ml}$. were used for the dye injection.

Determinations were made under basal conditions with the subject in hed. After 
withdrawal of a dye-free sample and the injection of the dye solution into an arm vein, further blood samples were taken from a vein in the other arm at 10, 15, 20, 25 and $30 \mathrm{~min}$. after injection. Heparin was used as an anticoagulant. The dye concentrations at zero time were estimated by the extrapolation backwards of the disappearance curve to zero time. The first determinations of plasma volume in the German group were carried out at the end of a 28 day period during which the diet intake was controlled. The last observation was made on the last day of observation of each subject.

\section{Thiocyanate-space volume (SCN space)}

Determinations of the SCN space were carried out only in the German group and simultaneously with the plasma-volume determinations. The method used was that described by Bowler (1944) and by Rutstein, Thomson, Tolmach, Walker \& Floody (1945). Five hundred $\mathrm{mg}$. of sodium thiocyanate and ro $\mathrm{mg}$. of $\mathrm{T} 1824$ dissolved in ro ml. of $0.9 \% \mathrm{NaCl}$ solution formed the injection solution. In addition to the samples taken for the dye estimations, blood samples were taken at 40 and $50 \mathrm{~min}$. after injection. The concentration of thiocyanate was estimated in all the samples and plotted against time. If a distinct break occurred in the graph between the curve representing the process of dispersion of thiocyanate in the body fluids and that representing disappearance from the body, the time at which this occurred was regarded as the time of equilibrium, and the concentration at that time was regarded as the equilibrium concentration and was used to estimate the SCN space. If no distinct break occurred, equilibrium time was estimated from the mean time for the subjects tested previously, and the concentration at this estimated equilibrium time used to calculate $\mathrm{SCN}$ space.

The SCN space was calculated in 1 . and also as a percentage of the body-weight. The relative $\mathrm{SCN}$ space can be found from that expressed as percentage of body-weight by moving the decimal point one place to the right, when the value becomes SCN space as ml./kg. body-weight. The calculated normal SCN space values were obtained by multiplying the normal body-weight by the mean normal value for the $\mathrm{SCN}$ space (23.5\% of the body-weight) found by Henschel et al. (1947). It was assumed by these workers, and also by us, that the sp.gr. of the SCN fluid was that of water, i.e. I 1 . weighed I kg.

The subjects had, on the 28th day, either a trace of oedema demonstrable by pressure over the ankles or the shins under basal conditions in the morning, or a slight swelling in the same region, or no trace of oedema. Oedema when present on the 28th day disappeared completely by the $5^{8 \text { th }}$ day.

\section{RESULTS}

\section{Plasma- or serum-protein concentration}

The values obtained are set out in Table $\mathrm{x}$. These are the concentrations found in the Dutch group within $48 \mathrm{hr}$. after they came under our observation and in the German group at the end of a period of 28 days on a controlled dietary intake. The ages and sex of the various subjects are listed and the degree of oedema given an arbitrary grading. Inspection of Table I shows that the total plasma- or serum-protein concentrations 
fall into two groups: (a) thirty-four concentrations above $5 \mathrm{~g}$. protein/100 $\mathrm{ml}$., and (b) four concentrations below $5 \mathrm{~g}$. protein/100 $\mathrm{ml}$. While the presence or absence of oedema, or the degree of oedema, had no obvious correlation with the plasma-protein concentration in the first group, all subjects in the second group had oedema. Only one albumin level below $2.5 \mathrm{~g} . / 100 \mathrm{ml}$. was recorded (patient F.), and this level was associated with a total protein of $4.6 \mathrm{~g} . / 100 \mathrm{ml}$. and the presence of massive oedema.

Table I. Plasma- or serum-protein concentrations of Dutch and German groups, within $48 \mathrm{hr}$. of admission to hospital (Dutch) or of commencement of period of observation (German)

\begin{tabular}{|c|c|c|c|c|c|}
\hline Subject & Sex & Age & $\begin{array}{l}\text { Oedema, } \\
\text { grade of } \\
\text { severity" }\end{array}$ & $\begin{array}{c}\text { protein } \\
\text { concentration } \\
(\mathrm{g} . / 100 \mathrm{ml} .) \dagger\end{array}$ & $\begin{array}{c}\text { Albumin } \\
\text { concentration } \\
\text { (g. } / 100 \mathrm{ml} \text {.) }\end{array}$ \\
\hline \multicolumn{6}{|c|}{ Dutch group } \\
\hline Sp. & $\mathrm{F}$ & 54 & 2 & 6.90 & 3.90 \\
\hline $\mathrm{Zn}$. & M. & 48 & 3 & $7 \cdot 78$ & $4 \cdot 54$ \\
\hline Vr. & $\mathrm{F}$ & & 2 & $6 \cdot 27$ & 3.90 \\
\hline T.Jr. & M. & $2 x$ & $\mathbf{I}$ & $7.55(\mathrm{~s})$ & $4 \cdot 61$ \\
\hline D. & F. & 53 & ० & $6.25(s)$ & $3 \cdot 18$ \\
\hline Fr. & F. & 44 & 2 & $5.9 \times(\mathrm{s})$ & 3.32 \\
\hline T. & F. & 55 & 2 & $5^{25}(\mathrm{~s})$ & $3 \cdot 16$ \\
\hline V.V. & F. & 52 & 3 & $6 \cdot 28$ & 3.56 \\
\hline$F$ & M. & 77 & M & $4 \cdot 60(s)$ & $2 \cdot 09$ \\
\hline Bg. & M. & 74 & I & $6.62(s)$ & $4 \cdot 56$ \\
\hline w. & F. & 62 & 3 & $6.70(s)$ & $4 \cdot 34$ \\
\hline O. & $\mathbf{F}$ & 53 & 4 & $5.44(s)$ & $3 \cdot 80$ \\
\hline v.B. & M. & 45 & 3 & 4.92 & 一 \\
\hline d.B. & M. & $5^{2}$ & 4 & 477 & - \\
\hline Ht. & M. & 43 & 0 & $6 \cdot 25$ & - \\
\hline K. & M. & 50 & o & $6 \cdot 39$ & - \\
\hline Jn. & M. & 30 & 3 & 4.84 & - \\
\hline St. & M. & 46 & 2 & 5.98 & - \\
\hline v.d.H. & M. & 60 & 0 & $6 \cdot 47$ & - \\
\hline B. & M. & 45 & 2 & $7 \cdot 10$ & 3.27 \\
\hline V.A. & M. & 57 & 0 & $6.54(s)$ & $3 \cdot 66$ \\
\hline T.Sr. & M. & 52 & $\circ$ & 6.75 & 3.46 \\
\hline d.G. & M. & $5^{8}$ & 0 & $673(s)$ & $4 \cdot 64$ \\
\hline Z. & F. & 62 & 1 & $6.52(s)$ & 4.05 \\
\hline v. & F. & 66 & 0 & $6.88(s)$ & 4.46 \\
\hline E. & M. & 36 & I & $7 \cdot 23(\mathrm{~s})$ & $4 \cdot 46$ \\
\hline $\mathrm{J}$ & M. & 59 & 2 & $6 \cdot 5^{\circ}(\mathrm{s})$ & $3 \cdot 35$ \\
\hline \multicolumn{6}{|c|}{ German group } \\
\hline Ks. & M. & 21 & I & 6.95 & - \\
\hline Lv. & M. & 21 & I & 6.74 & - \\
\hline Kl. & M. & 25 & 0 & 6.02 & - \\
\hline Wz. & M. & $3 x$ & I & $6 \cdot 22$ & - \\
\hline Sc. & M. & 25 & 1 & $6 \cdot 41$ & - \\
\hline Gm. & M. & 52 & I & $6 \cdot 25$ & - \\
\hline Gt. & M. & 24 & $\mathbf{I}$ & $6 \cdot 72$ & - \\
\hline Rs. & M. & 21 & 0 & $7 \cdot 06$ & - \\
\hline Gd. & M. & 22 & I & $7 \cdot 22$ & - \\
\hline $\mathrm{Bm}$. & M. & 25 & 0 & $7 \cdot 21$ & - \\
\hline Ru. & M. & 27 & I & $6 \cdot 47$ & - \\
\hline
\end{tabular}

- Grading of oedema: 0 , no oedema; $x$, no visible oedema but pitting on pressure over shin, tendo Achillis, or dorsum of foot; 2 , visible oedema of ankle and foot; 3 , oedema extending to level of knee; 4, oedema to level of inguinal ligament; $M$, massive oedema of all four limbs and trunk.

$t(s)$ indicates that serum (not plasma) proteins were estimated. 
The effect of prolonged dietetic treatment on the level of the plasma proteins is shown in Table 2. Where the total protein level was low at the first determination, there was a variable increase in concentration. When the total proteins were within the normal limits, the change after treatment was inconstant in amount and direction. It will be noted that patient $F$., who had massive oedema, showed a marked rise from 4.6 to $5.97 \mathrm{~g}$./100 ml. over a period of 34 days. In spite of this rise, however, there was considerable residual oedema at the end of the period of observation.

Table 2. Plasma- or serum-protein concentrations of Dutch and German groups at beginning and at end of period of refeeding

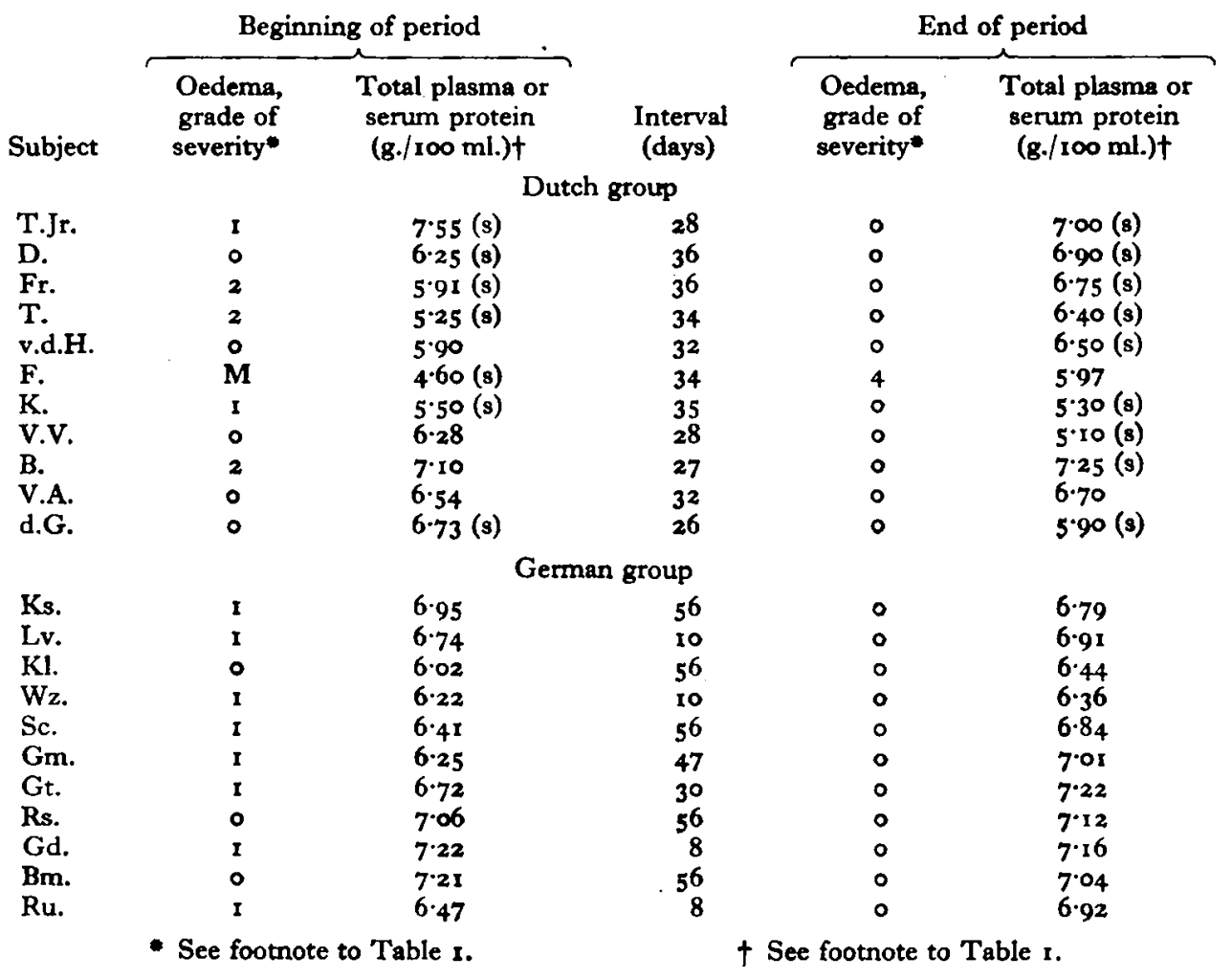

\section{Plasma volume}

The relevant data are set out in Table 3. The absolute plasma volumes were determined, and from these the relative plasma volumes (ml. $/ \mathrm{kg}$. body-weight) were computed. A calculated normal plasma volume is given for each subject. This was obtained by taking the mean value of $45.3 \mathrm{ml} . / \mathrm{kg}$. for the two control normal groups recorded by Henschel et al. (1947), and multiplying by the known normal weight of each subject.

\section{Thiocyanate-space volume (SCN space)}

The results of the study made on the German subjects are set out in Tables 4-6. These have been compiled to afford ready comparison with the studies of Henschel et al. (1947). 
Table 5 contains the mean, maximum and minimum values for the SCN space expressed as percentages of the observed body-weight for different days of observation during increased food intake. The mean absolute SCN space is also given.

Table 6 has been constructed to show the mean absolute amount of the 'excess SCN space or thiocyanate oedema fluid' at each day of observation.

Table 3. Comparison of the plasma volume actually found with the calculated normal plasma volume, and of relative plasma volume with the percentage fall in body-weight (Dutch and German groups)

\begin{tabular}{|c|c|c|c|c|c|}
\hline \multirow[b]{3}{*}{ Subject } & \multirow[b]{3}{*}{ Date } & \multicolumn{3}{|c|}{ Plasma volume } & \multirow{3}{*}{$\begin{array}{c}\text { Fall in } \\
\text { body-weight } \\
\text { from normal } \\
(\%)\end{array}$} \\
\hline & & \multirow[b]{2}{*}{$\begin{array}{c}\text { Calculated } \\
\text { normal } \\
(1 .)\end{array}$} & \multicolumn{2}{|c|}{ Found } & \\
\hline & & & 1. & $\begin{array}{c}\text { Relative } \\
\text { (ml./kg. } \\
\text { body-weight) }\end{array}$ & \\
\hline \multicolumn{6}{|c|}{ Dutch group } \\
\hline v.A. & $\begin{array}{l}20 \text { May } \\
\text { I I June }\end{array}$ & $\begin{array}{l}3 \cdot 37 \\
3 \cdot 37\end{array}$ & $\begin{array}{l}2 \cdot 73 \\
2 \cdot 91\end{array}$ & $\begin{array}{l}6 \mathrm{I} \cdot 1 \\
63 \cdot 0\end{array}$ & $\begin{array}{l}40 \\
38\end{array}$ \\
\hline d.G. & $\begin{array}{l}\text { 21 May } \\
12 \text { June }\end{array}$ & $\begin{array}{l}3 \cdot 17 \\
3 \cdot 17\end{array}$ & $\begin{array}{l}3 \cdot 13 \\
3 \cdot 63\end{array}$ & $\begin{array}{l}62 \cdot 6 \\
66 \cdot 0\end{array}$ & $\begin{array}{l}29 \\
21\end{array}$ \\
\hline Z. & 14 June & 3.04 & 2.92 & $68 \cdot 2$ & 36 \\
\hline E. & $\begin{array}{l}15 \text { June } \\
28 \text { June }\end{array}$ & $\begin{array}{l}3.44 \\
2.54\end{array}$ & $\begin{array}{l}3.84 \\
3.08\end{array}$ & $\begin{array}{l}69.4 \\
73.5\end{array}$ & $\begin{array}{l}27 \\
25\end{array}$ \\
\hline J. & $\begin{array}{l}14 \text { June } \\
28 \text { June }\end{array}$ & $\begin{array}{l}2 \cdot 54 \\
2 \cdot 54\end{array}$ & $\begin{array}{l}2.97 \\
3.08\end{array}$ & $\begin{array}{l}74^{\circ} \circ \\
73^{\circ} 5\end{array}$ & 29 \\
\hline V. & 19 May & $2 \cdot 94$ & $2 \cdot 52$ & 63.0 & $3^{8}$ \\
\hline V.V. & $\begin{array}{l}\text { 2I May } \\
\text { II. June }\end{array}$ & $\begin{array}{l}2.83 \\
2.83\end{array}$ & $\begin{array}{l}2.67 \\
3.00\end{array}$ & $\begin{array}{l}63.4 \\
68 \cdot 0\end{array}$ & $\begin{array}{l}33 \\
29\end{array}$ \\
\hline $\mathbf{T}$ & 22 May & $2 \cdot 72$ & $2 \cdot 99$ & $78 \cdot 7$ & 37 \\
\hline & 12 June & $2 \cdot 72$ & $2 \cdot 84$ & 747 & 37 \\
\hline K. & 22 May & $2 \cdot 99$ & $3 \cdot 30$ & $82 \cdot 9$ & $4^{\circ}$ \\
\hline Fr. & $\begin{array}{l}27 \text { May } \\
\text { 13 June }\end{array}$ & $\begin{array}{l}2 \cdot 76 \\
2 \cdot 76\end{array}$ & $\begin{array}{l}2.58 \\
2.50\end{array}$ & $\begin{array}{l}72 \cdot 3 \\
67 \cdot 2\end{array}$ & $\begin{array}{l}41 \\
39\end{array}$ \\
\hline D. & 27 May & $\begin{array}{l}3.13 \\
3.13\end{array}$ & $\begin{array}{l}2.73 \\
3.30\end{array}$ & $\begin{array}{l}78 \cdot 0 \\
85 \cdot 7\end{array}$ & 49 \\
\hline VI. & 26 June & $\begin{array}{l}3.13 \\
2.65 \\
2.65\end{array}$ & $\begin{array}{l}3 \cdot 30 \\
2 \cdot 29 \\
2 \cdot 47\end{array}$ & $\begin{array}{l}74.4 \\
65.5\end{array}$ & $\begin{array}{l}47 \\
36\end{array}$ \\
\hline \multicolumn{6}{|c|}{ German group } \\
\hline K8. & $\begin{array}{l}\text { 3I July } \\
25 \text { Sept. }\end{array}$ & $\begin{array}{l}3.22 \\
3.22\end{array}$ & $\begin{array}{l}3.51 \\
3.39\end{array}$ & $\begin{array}{l}63.3 \\
58.8\end{array}$ & $\begin{array}{l}22 \\
19\end{array}$ \\
\hline Lv. & 3o July & $3 \cdot 31$ & 3.49 & $63 \cdot 5$ & 25 \\
\hline $\mathrm{Kl}$. & 30 July & $2 \cdot 94$ & 3.06 & 57.5 & $\times 8$ \\
\hline & 23 Sept. & $2 \cdot 94$ & $2 \cdot 79$ & 50.5 & 15 \\
\hline Wz. & 3I.July & $3 \cdot 24$ & $3 \cdot 15$ & $5^{8 \cdot 5}$ & 25 \\
\hline Sc. & 30 July & $3 \cdot 13$ & $3 \cdot 34$ & $60 \cdot 0^{\circ}$ & 19 \\
\hline & 24 Sept. & $3 \cdot 13$ & $3 \cdot 14$ & $53 \cdot 7$ & I5 \\
\hline Gm. & I Aug. & $3 \cdot 19$ & $3 \cdot 25$ & $64 \cdot 8$ & 29 \\
\hline & I 5 Sept. & $3 \cdot 19$ & 3.00 & $58 \cdot 0$ & 27 \\
\hline Gt. & I Aug. & $3 \cdot 31$ & $3 \cdot 33$ & $70 \cdot 5$ & 33 \\
\hline & 3 I Aug. & $3 \cdot 31$ & 2.98 & $59 \cdot 5$ & $3 I$ \\
\hline Rs. & I Aug. & $3 \cdot 04$ & $3 \cdot 10$ & $56 \cdot 1$ & 17 \\
\hline & 25 Sept. & 3.04 & $2 \cdot 88$ & $5 I \cdot 5$ & $\times 7$ \\
\hline Gd. & 2 Aug. & 3.13 & $3 \cdot 17$ & 69.7 & 34 \\
\hline & Io Aug. & $3 \cdot 13$ & 3.27 & $72 \cdot 2$ & 34 \\
\hline Bm. & 2 Aug. & $2 \cdot 94$ & 3.48 & $66 \cdot 9$ & 26 \\
\hline & 25 Sept. & $2 \cdot 94$ & $2 \cdot 88$ & $55 \cdot 4$ & 20 \\
\hline Ru. & $\begin{array}{l}2 \text { Aug. } \\
\text { 10 Aug. }\end{array}$ & $\begin{array}{l}3.17 \\
3.17\end{array}$ & $\begin{array}{l}2.99 \\
2.80\end{array}$ & $\begin{array}{l}55 \cdot 7 \\
52 \cdot 8\end{array}$ & $\begin{array}{l}23 \\
24\end{array}$ \\
\hline
\end{tabular}


Table 4. Comparison of calculated normal* SCN space with that actually found (German group)

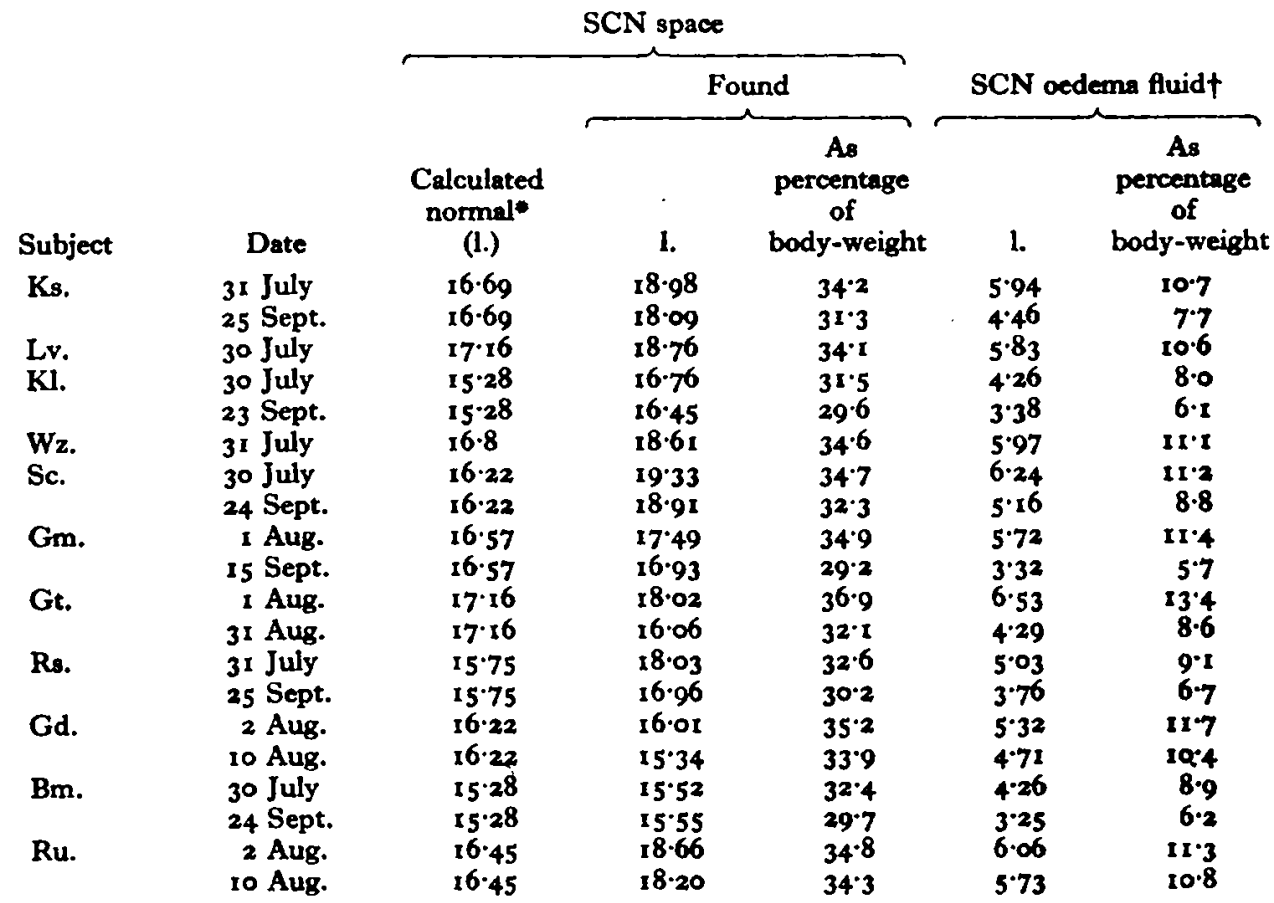

- The normal SCN space is calculated as $23.5 \%$ of the body-weight of the subjects in the normal state (Beattie \& Herbert, 1947, Table I).

+ The SCN oedema fluid is the difference between the SCN space found and that calculated as $23.5 \%$ of the observed body-weight (Beattie \& Herbert, 1947, Table 2).

\section{Table 5." Changes in the mean SCN space during the period of refeeding (German group)}

The numbers of days given are counted from the beginning of an increased food intake after a control period of 28 days of semi-starvation.

\section{SCN space as percentage of body-weight}

\section{Mean}

Maximum

Minimum

8.D. of observations

Mean SCN space (1.)

No. of observations

\begin{tabular}{ccccc}
\hline 0 & 8 & 30 & 47 & 56 \\
34.2 & 34.1 & $32 \cdot 1$ & 29.2 & 30.6 \\
36.9 & 34.3 & - & - & 32.3 \\
31.5 & 33.9 & - & - & 29.6 \\
\pm 1.43 & - & - & - & \pm 1.04 \\
17.83 & 16.77 & 16.06 & 16.93 & 17.19 \\
11 & 2 & 1 & 1 & 5
\end{tabular}

Days on increased food intake

- This Table is set up in a manner similar to that of the corresponding Table in the paper of Henschel et al. (1947).

\section{DISCUSSION}

Famine oedema as we saw it in Holland in 1945 and in Germany in 1946 could be divided into two types each with well-marked clinical and biochemical features. The first type, which was more common, was usually of slight or moderate severity. It 
appeared in the feet and ankles and over the subcutaneous area of the tibia in the afternoon or evening. It usually disappeared with rest in bed only to reappear the following afternoon or evening. It became worse if exercise was severe or prolonged or if the subject had to remain in an erect posture during the day. Frequently it was

Table 6.* Mean values for SCN oedema fluid + during the period of refeeding (German group)

Mean observed SCN space (1.)

Mean calculated $\mathrm{SCN}$ space (1.)

Mean excess SCN space (SCN oedema fluid) (1.)

Mean excess SCN space as percentage of observed body-weight

No. of observations
Days on increased food intake

\begin{tabular}{ccccc}
\hline 0 & \multicolumn{1}{c}{8} & \multicolumn{1}{c}{30} & 47 & 56 \\
17.83 & 16.77 & 16.06 & 16.93 & 17.19 \\
12.27 & 11.55 & 11.77 & 13.61 & 13.19 \\
5.56 & 5.22 & 4.29 & 3.32 & 4.00 \\
10.7 & 10.6 & 8.6 & 5.7 & 7.1 \\
11 & & & & 5
\end{tabular}

+ See footnote to Table 4 .

- See footnote to Table 5 .

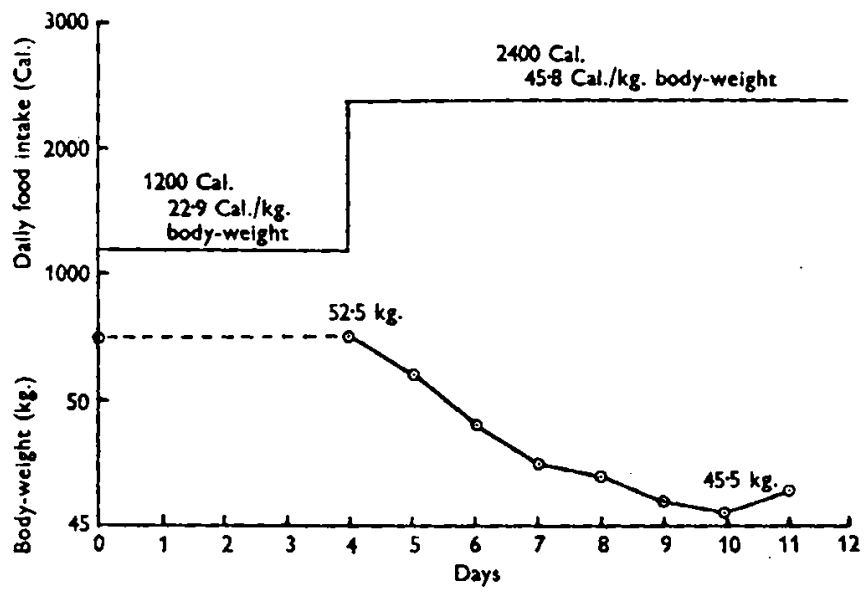

Fig. I. The effect of increased food intake on body-weight (nude) in a patient with slight oedema but with normal plasma-protein concentration $(6.39 \mathrm{~g} . / 100 \mathrm{ml}$.). This is an example of isohydric famine oedema (patient K., Dutch group). — Food intake; $\odot-\ldots . \odot$ body-weight before period of refeeding; $\odot-\odot$ body-weight after period of refeeding.

reported by patients to have been precipitated for the first time by a long walk or cycle ride into the country in an attempt to secure extra food. Rest in bed usually sufficed to disperse the swelling, and only rarely did an oedema beginning after such exercise persist in spite of bed rest. When such persons were admitted to hospital and given diets which enabled them to achieve positive nitrogen balance (more than $35 \mathrm{Cal}$. and $0.17 \mathrm{~g}$. protein $\mathrm{N} / \mathrm{kg}$. body-weight/day) the oedema disappeared rapidly and at the same time the body-weight fell, owing largely to an increased urinary output. This fall in body-weight continued in some individuals for around 7 days, after which the weight became stabilized or began to increase slowly (Fig. I). Biochemical investigations revealed that in this type of oedema the total plasma proteins and the albumin fraction 
were either within the limits of normal or remained above the so-called critical levels for hypoproteinaemia found by Weech \& Ling (193I).

The second type was much less common. Four individuals in the Dutch series, subjects F., v.B., d.B. and Jn., fell into this type. It was not encountered in May and June 1946 among the prison populations in the area of the British Zone of Germany, from which we selected our first group of fifty men and from whom the final group of eleven men was selected for detailed study. A few examples of this type were observed,

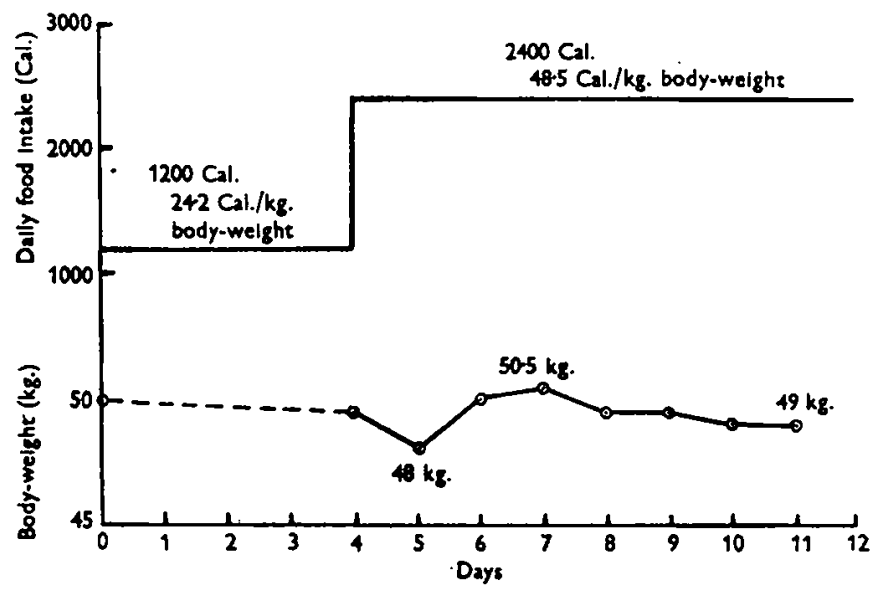

Fig. 2. The effect of increesed food intake on body-weight (nude) in a patient with oedema and a low plasma-protein concentration $(4.84 \mathrm{~g} / 100 \mathrm{ml}$.). This is an example of hypoproteinaemic famine oedema (patient Jn., Dutch group). - Food intake; $\odot \ldots .-\odot$ body-weight before period of refeeding; $\odot \longrightarrow \odot$ body-weight after period of refeeding.

but not studied in detail, in middle-aged and older persons found as patients in hospitals and old peoples' homes in Germany. The oedema varied in severity from oedema of the lower limbs to massive oedema involving all four limbs and the whole trunk. Hydrothorax and hydroperitoneum were not found except possibly for a brief period in one patient. The oedema, instead of disappearing with rest in bed, persisted and tended to increase slowly. It was found that such persons, when admitted to hospital, had a very low urinary output (less than $1 \mathrm{l}$./day) even when kept on a constant fluid intake of $1 \cdot 5-2 \cdot 01$. day. Biochemical investigation showed that in them the total plasma proteins were less than $5 \mathrm{~g} . / 100 \mathrm{ml}$, and the albumin portion, when determined, was less than $2.5 \mathrm{~g} . / 100 \mathrm{ml}$.

The provision of a diet, which in the first type of oedema would have brought about a rapid fall in body-weight and diuresis, failed in the second type to bring about this immediate response. If the fluid intake was maintained at $21 . /$ day and the calorie and protein intake were sufficient to ensure positive nitrogen balance (Beattie et al. 1947), a fall in body-weight with a coincident diuresis (over $21 . /$ day) was found to occur after a delay of 4-7 days. This diuresis lasted for about a week, after which the urinary output on a constant fluid intake returned to around 1.5 1./day (Fig. 2).

Information about the weight changes during the period of food deprivation was not available for the series of twenty patients studied in The Hague during May- 
July 1945 , but records of the body-weights of patients studied in a mental hospital near Zutphen provided useful information. Up to the beginning of December 1944 the patients in this hospital had been provided with an adequate diet and had shown a constant body-weight up to that time. A reduction in food intake to around 1700 Cal./ day took place at the beginning of March 1945, and this level was maintained with difficulty until the hospital was freed by the Allied Forces in the third week of April 1945 .

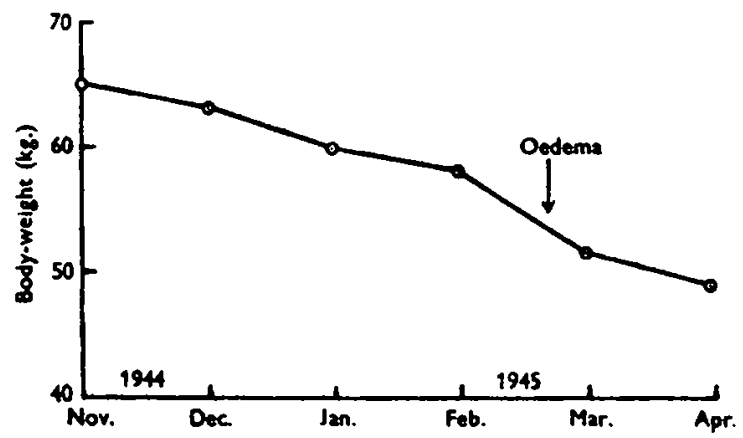

Fig. 3. The fall in body-weight (nude) as the result of a severe reduction in food intake. The onset of oedema does not produce any break in the weight-fall curve. Plasma-protein concentration at end of period of food deprivation was $6.39 \mathrm{~g} . / \mathrm{r} 00 \mathrm{ml}$. An example of isohydric famine oedema (patient K., Dutch group).

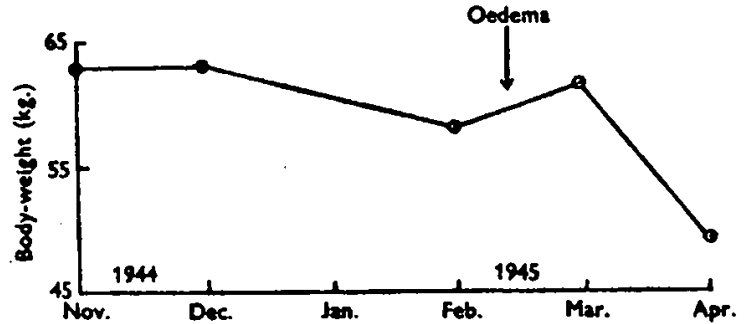

Fig. 4. The fall in body-weight (nude) following reduction in food intake. The onset of marked oedema leads to a rise in body-weight. Plasma-protein concentration at end of period of food deprivation was $4.84 \mathrm{~g} .100 \mathrm{ml}$. An example of hypoproteinaemic famine oedema (patient Jn., Dutch group).

The monthly weight records of the patients in this mental hospital were examined and it was found that there were two patterns of weight loss. Some showed an uninterrupted fall in body-weight from December to April in spite of the appearance of oedema (Fig. 3). This oedema disappeared after rest in bed only to reappear when physical effort or prolonged standing occurred. The plasma protein concentrations, though low, were still above the 'oedema' limit of Weech \& Ling (193I) (Table I, subjects Ht., K. and St.).

Three patients, however, showed at some time between December and April a marked increase in body-weight related to the appearance of oedema which persisted in spite of bed rest (Fig. 4). These patients showed plasma-protein concentrations which were less than $5^{\circ} \circ \mathrm{g}$. protein $/ 100 \mathrm{ml}$. The administration of a diet adequate to secure positive nitrogen balance and bed rest was not followed in such patients by a rapid disappearance of the oedema (see Fig. 2). The delayed response, however, took 
place. Unfortunately, it was not possible to continue this study in detail beyond a period of $\mathrm{I}$ days as the military situation had changed rapidly, and it was necessary to prepare to enter western Holland and commence work at The Hague.

The Dutch and German subjects on whom plasma volumes were determined showed oedema of the first type, i.e. with plasma- or serum-protein concentrations greater

Table 7. Analysis of the differences between the observed plasma volumes and the calculated normal plasma volumes in the Dutch group

\begin{tabular}{|c|c|c|c|c|}
\hline & Obse & ons & & \\
\hline Subject & $\begin{array}{c}\text { Differences } \\
\text { from calculated } \\
\text { normal } \\
\text { (l.) }\end{array}$ & $\begin{array}{l}\text { Squares of } \\
\text { differences }\end{array}$ & $\begin{array}{c}\text { Pooled } \\
\text { differenoes } \\
\text { (1.) }\end{array}$ & $\begin{array}{l}\text { Sums of } \\
\text { squares of } \\
\text { pooled } \\
\text { differences }\end{array}$ \\
\hline v.A. & $\begin{array}{l}-0.64 \\
-0.46\end{array}$ & $\begin{array}{l}0.4096 \\
0.2116\end{array}$ & $-1 \cdot 10$ & 0.6050 \\
\hline d.G. & $\begin{array}{l}-0.04 \\
+0.46\end{array}$ & $\begin{array}{l}0.0016 \\
0.2116\end{array}$ & +0.42 & 0.0882 \\
\hline Z. & -0.12 & 0.0144 & -0.12 & 0.0144 \\
\hline E. & $\begin{array}{l}+0.40 \\
+0.10\end{array}$ & $\begin{array}{l}0.1600 \\
0.0100\end{array}$ & +0.50 & 0.1250 \\
\hline J. & $\begin{array}{l}+0.43 \\
+0.54\end{array}$ & $\begin{array}{l}0.1849 \\
0.2916\end{array}$ & +0.97 & 0.4705 \\
\hline $\begin{array}{l}\text { V. } \\
\text { V.V. }\end{array}$ & $\begin{array}{r}-0.42 \\
-0.16 \\
+0.17\end{array}$ & $\begin{array}{l}0.1764 \\
0.0256 \\
0.0289\end{array}$ & $\begin{array}{l}-0.42 \\
+0.01\end{array}$ & $\begin{array}{l}0.1764 \\
0.0001\end{array}$ \\
\hline$T$. & $\begin{array}{l}+0.27 \\
+0.12\end{array}$ & $\begin{array}{l}0.0729 \\
0.0144\end{array}$ & +0.39 & $0.076 \mathrm{I}$ \\
\hline $\mathbf{K}$ & +0.31 & $0 \cdot 096 \mathrm{r}$ & +0.31 & $0.0066 \mathrm{r}$ \\
\hline Fr. & $\begin{array}{l}-0.18 \\
-0.26\end{array}$ & $\begin{array}{l}0.0324 \\
0.0676\end{array}$ & -0.44 & 0.0968 \\
\hline D. & $\begin{array}{l}-0.60 \\
+0.17\end{array}$ & $\begin{array}{l}0.3600 \\
0.0289\end{array}$ & -0.43 & 0.0925 \\
\hline Vr. & $\begin{array}{l}-0.36 \\
-0.28\end{array}$ & $\begin{array}{l}0.1296 \\
0.0324\end{array}$ & -0.54 & $0.145^{8}$ \\
\hline Total & +0.63 & $2 \cdot 5605$ & +0.63 & $1 \cdot 9869$ \\
\hline & & $\begin{array}{l}\text { Sum of } \\
\text { squares }\end{array}$ & $\begin{array}{c}\text { Degrees of } \\
\text { freedom }\end{array}$ & $\begin{array}{l}\text { Mean } \\
\text { square }\end{array}$ \\
\hline $\begin{array}{l}\text { Grand } \\
\text { Individ } \\
\text { Error }\end{array}$ & $\begin{array}{l}\text { tion } \\
\text { ifferences }\end{array}$ & $\begin{array}{l}0.0189 \\
1.9680 \\
0.5736\end{array}$ & $\begin{array}{r}I \\
\text { II } \\
9\end{array}$ & $\begin{array}{l}0.0189 \\
0.1789 \\
0.0637\end{array}$ \\
\hline & & $2 \cdot 5605$ & 21 & - \\
\hline
\end{tabular}

than $5 \mathrm{~g} / 100 \mathrm{ml}$. As already stated (p. 47) the Dutch group contained individuals of both sexes and of ages between 21 and 77 years. On the other hand, the German subjects were males between the ages of $2 \mathrm{I}$ and $3 \mathrm{r}$ years except for one individual whose age was 52 years. The findings for each group, therefore, are considered separately below. Henschel et al. (1947) showed in their normal control series that the mean normal plasma volume was $45.3 \mathrm{ml} / \mathrm{kg}$. body-weight, and found, moreover, after a period of semi-starvation, that the absolute plasma volume had remained almost unchanged. As in our study no normal plasma volumes were available for comparison with those found in the semi-starvation state, the absolute normal plasma volume was calculated for each subject from the above value and the known normal body-weight 
of the subject. If it could be shown that in the Dutch and German subjects there was no significant difference between the observed absolute plasma volumes and the calculated normal volumes, it would be permissible to conclude that these subjects behaved in the same way as those studied by Henschel et al. (1947).

Table 8. Analysis of the differences between the observed plasma volumes and the calculated normal plasma volumes in the German group

\begin{tabular}{|c|c|c|c|c|}
\hline \multirow[b]{2}{*}{ Subject } & \multicolumn{2}{|c|}{ Observations } & \multicolumn{2}{|c|}{ Individuals } \\
\hline & $\begin{array}{l}\text { Differences } \\
\text { from calculated } \\
\text { normal } \\
(1 .)\end{array}$ & $\begin{array}{l}\text { Squares of } \\
\text { differences }\end{array}$ & $\begin{array}{l}\text { Pooled } \\
\text { differences } \\
\text { (1.) }\end{array}$ & $\begin{array}{l}\text { Sums of } \\
\text { squares of } \\
\text { pooled } \\
\text { differences }\end{array}$ \\
\hline Ks. & $\begin{array}{r}+0.29 \\
+0.17\end{array}$ & $\begin{array}{l}0.0841 \\
0.0289\end{array}$ & +0.46 & $0 \cdot 1058$ \\
\hline Lv. & +0.18 & 0.0324 & +0.18 & 0.0324 \\
\hline $\mathrm{Kl}$. & $\begin{array}{l}+0.12 \\
-0.15\end{array}$ & $\begin{array}{l}0.0144 \\
0.0225\end{array}$ & -0.03 & 0.0005 \\
\hline Wz. & -0.09 & $0.008 \mathrm{I}$ & -0.09 & 0.008 I \\
\hline Sc. & $\begin{array}{l}+0.21 \\
+0.01\end{array}$ & $\begin{array}{l}0.0441 \\
0.0001\end{array}$ & +0.22 & 0.0242 \\
\hline $\mathrm{Gm}$. & $\begin{array}{l}+0.06 \\
-0.19\end{array}$ & $\begin{array}{l}0.0036 \\
0.0361\end{array}$ & -0.13 & 0.0084 \\
\hline Gt. & $\begin{array}{l}+0.02 \\
-0.33\end{array}$ & $\begin{array}{l}0.0004 \\
0.1089\end{array}$ & -0.31 & 0.0481 \\
\hline Rs. & $\begin{array}{l}+0.06 \\
-0.16\end{array}$ & $\begin{array}{l}0.0036 \\
0.0256\end{array}$ & -0.10 & 0.0050 \\
\hline Gd. & $\begin{array}{l}+0.04 \\
+0.14\end{array}$ & $\begin{array}{l}0.0016 \\
0.0196\end{array}$ & +0.18 & 0.0162 \\
\hline $\mathrm{Bm}$. & $\begin{array}{l}+0.54 \\
-0.06\end{array}$ & $\begin{array}{l}0.2916 \\
0.0036\end{array}$ & $+0.4^{8}$ & 0.1152 \\
\hline Ru. & $\begin{array}{l}-0.18 \\
-0.37\end{array}$ & $\begin{array}{l}0.0324 \\
0.1369\end{array}$ & -0.55 & 0.1512 \\
\hline Totals & +0.31 & 0.8985 & +0.31 & 0.5156 \\
\hline & & $\begin{array}{l}\text { Sum of } \\
\text { squares }\end{array}$ & $\begin{array}{c}\text { Degrees of } \\
\text { freedom }\end{array}$ & $\begin{array}{l}\text { Mean } \\
\text { square }\end{array}$ \\
\hline \multirow{3}{*}{\multicolumn{2}{|c|}{$\begin{array}{l}\text { Grand deviation } \\
\text { Individual differences } \\
\text { Error }\end{array}$}} & 0.02245 & I & 0.02245 \\
\hline & & $\begin{array}{l}0.49315 \\
0.38290\end{array}$ & $\begin{array}{r}10 \\
9\end{array}$ & $\begin{array}{l}0.04932 \\
0.04254\end{array}$ \\
\hline & & 0.89850 & 20 & \\
\hline
\end{tabular}

'The differences between the observed and calculated normal absolute values are set out in Tables 7 and 8 together with the results of an analysis of variance. The grand deviation (of all observations) in the Dutch and German series, taken separately or together, was not significant (Tables 7-9). There was thus no evidence that the observed plasma volume had changed significantly from the calculated normal. The two groups did not differ significantly in their mean deviations (Tables 3,7 and 8), but they did differ significantly in the size of the mean square for individual differences (Table 9). The Dutch group was more variable than the German group, as might be expected from the composition of the two groups. The German group, being more homogeneous, showed no greater variation between individuals than could be accounted for by the error term (Table 8). When the error variances for the two groups were examined, it was found that they were very similar (Tables 7,8 ). This finding was 
to be expected, as the error term depends on the technical methods and these were identical for both groups.

If, therefore, the absolute plasma volumes in the two groups of subjects had remained substantially unchanged, then as body-weight declined the relative plasma volume (ml./kg.) would increase. In Fig. 5 the percentage fall in body-weight has been graphed against the determined relative plasma volumes of all subjects. The theoretical relative

Table 9. Analysis of the group differences for plasma volumes (Dutch and German)

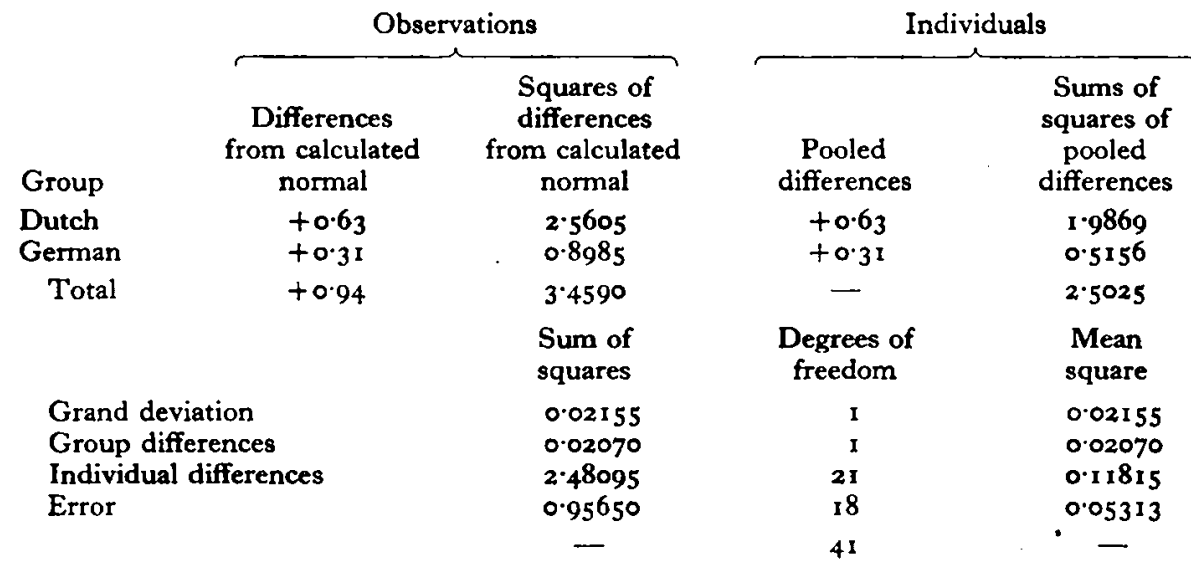

Variance ratio for all individual differences $=\frac{0 \cdot 11815}{0.05313}=2 \cdot 2$;

$$
n_{1}=21, n_{2}=18, P=0.05-0.01 \text {. }
$$

Variance ratio for group differences:

$$
\begin{aligned}
& \frac{\text { Mean square of individual differences (Dutch) }}{\text { Mean square of individual differences (German) }}=\frac{0.1789}{0.04932}=3.6 ; \\
& n_{1}=11, n_{2}=10, P=0.01-0.00 \mathrm{r} \text {. }
\end{aligned}
$$

plasma volume for given percentage reductions in body-weight was calculated and graphed. The observed relative plasma volumes scattered evenly around this theoretical curve.

The observations of SCN space, made on the German group only, were analysed in the same way as the plasma volumes. It was assumed that the absolute SCN space had not changed from the normal value. The normal value was calculated from the data given by Henschel et al. (1947), which showed that in normal individuals the SCN space can be expressed as $23.5 \%$ of the normal weight. Assuming that the fluid in this space had a sp.gr. of $\mathrm{I} \cdot 0$, the normal $\mathrm{SCN}$ space was calculated. The differences between calculated normal and observed SCN space were calculated and analysed (Table 4). There was a significant deviation of the observed absolute volume from the calculated normal absolute volume, as seen in the grand deviation value, even when this was measured against the mean square for individual differences (Table ro). There was thus no doubt that the SCN space as observed was greater than the normal calculated on the basis of the data of Henschel et al. (1947) $\left(t_{(n-10)}=2 \cdot 56\right)$. The individual differences were considerable as measured against the observational error (error term) (Table 10). 
In Fig. 6 the percentage fall in body-weight has been graphed against the relative $\mathrm{SCN}$ space $(\mathrm{ml} . / \mathrm{kg}$.). The theoretical relationship based on the assumption that the absolute SCN space remained constant in spite of weight loss has been plotted. The distribution of the observed points-to the left and above the theoretical curve-

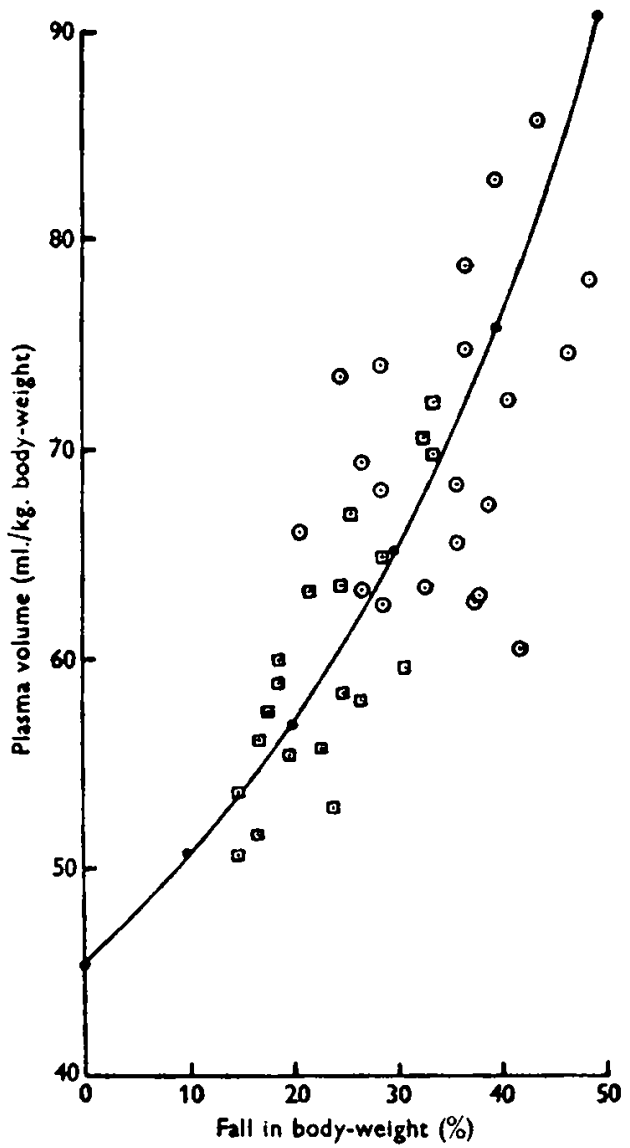

Fig. 5

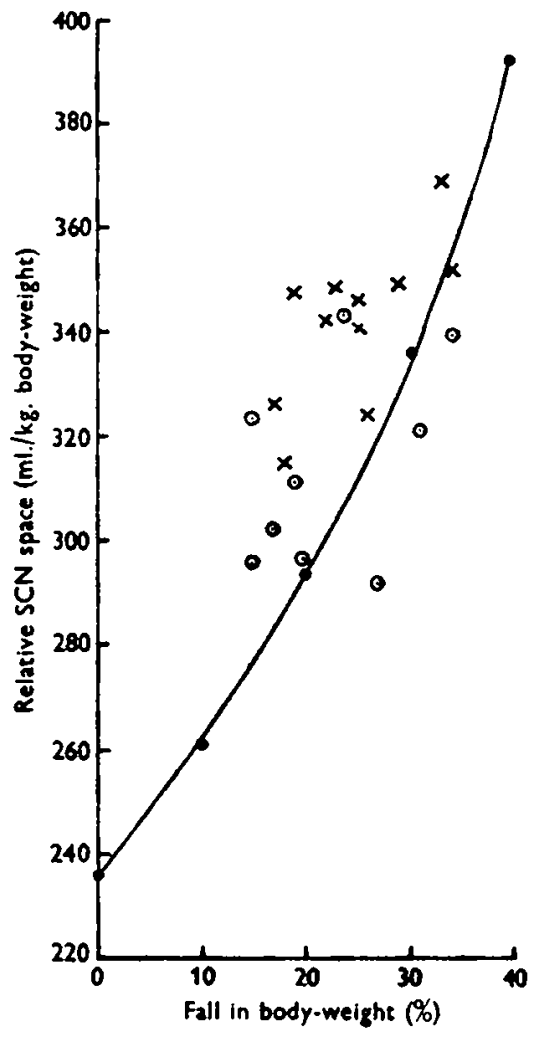

Fig. 6

Fig. 5. The theoretical increase in relative plasma volume (ml./kg. body-weight) with increasing weight loss plotted against the percentage weight loss. It is assumed that the plasma volume remains unchanged. Points marked $\odot$ indicate determined relative plasma volumes in the Dutch series and points marked $\square$ corresponding volumes in the German series.

Fig. 6. The theoretical increase in relative SCN space ( $\mathrm{ml} . / \mathrm{kg}$. body-weight) with increasing weight loss. The curve is drawn on the assumption that absolute SCN space remained unchanged with weight loss. Points marked $x$ indicate SCN space determined at the 28 th day of observation and those marked $\odot$ SCN space determined at later days. The SCN space shows a real increase at the 28 th day.

demonstrated that an increase in the SCN space had occurred. This conclusion agrees with that drawn by Henschel $e$ t al. (1947) from their data obtained after 24 weeks of semi-starvation.

Henschel et al. (1947) found in their series that there was a small but significant increase in the absolute plasma volume after 24 weeks of semi-starvation. Our data from the German group did not provide evidence of such an expansion. The data 
from the Dutch group cannot be considered as relevant to this point, as these individuals had their plasma volumes determined at varying times after the start of refeeding. In the German group, five individuals showed no significant change from the normal calculated absolute plasma volume after $5^{6}$ days of restricted refeeding. The mean

Table 10. Analysis of the differences between actually found SCN space and normal $S C N$ space calculated as $23.5 \%$ of normal body-zveight (German group)

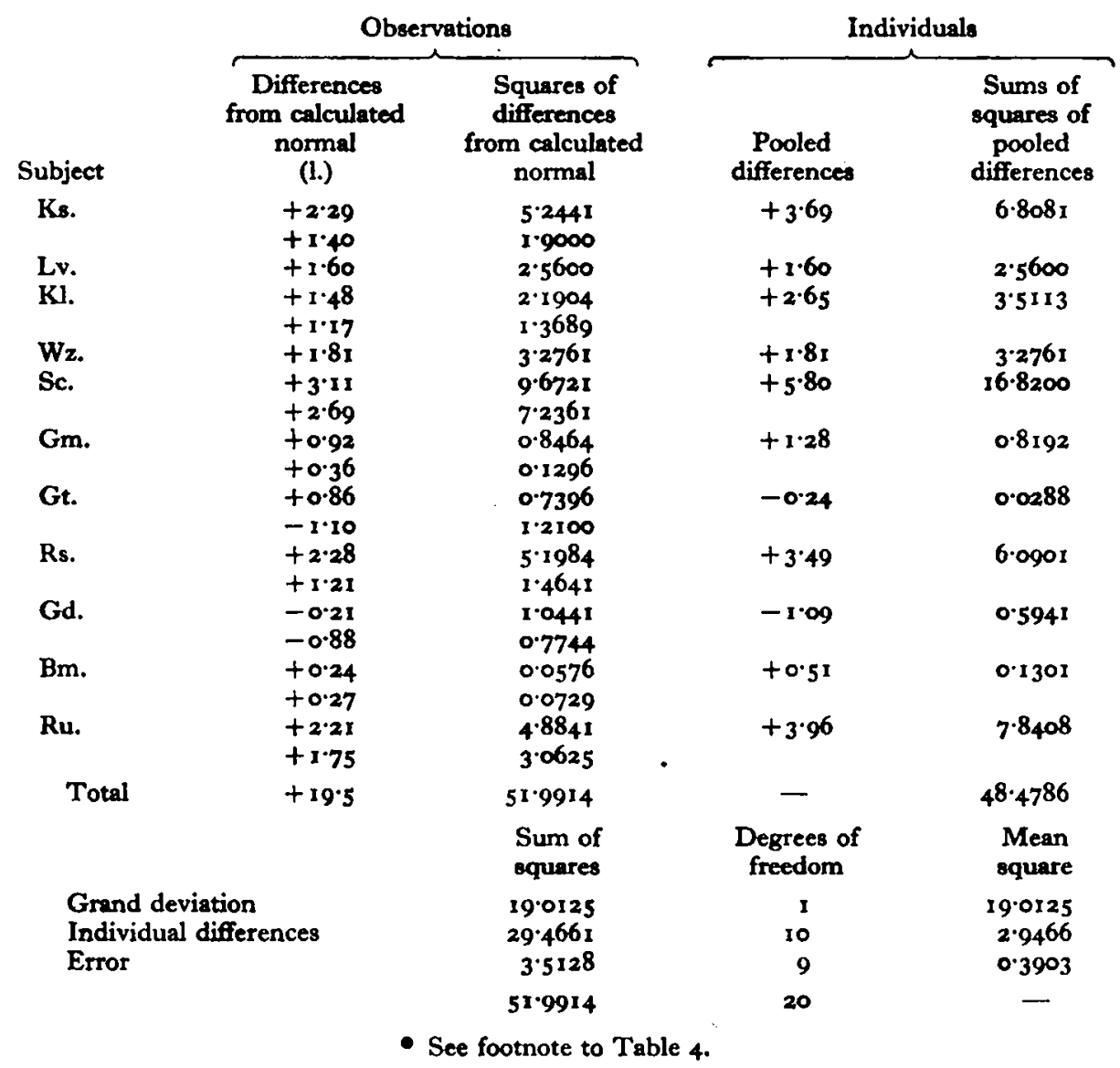

calculated normal volume was 3.054 1. (S.D. \pm 0.074 ), and the mean observed volume after $5^{6}$ days, $3^{\circ} \cdot{ }^{16}$ l. (S.D. $\pm 0^{\circ} 149$ ). The estimated standard deviation of combined calculated normal and observed volumes was \pm 0.064 , and the standard error of the difference between the means \pm 0.027 . The value for $t$ was therefore 1.4 , which gave a $P$ value between 0.2 and 0.1 .

For five members of the German group the SCN space was estimated after 56 days of restricted refeeding. The absolute changes in volume after this period were -0.89 , $-0.31,-0.42,-1.07$ and +0.031 . As individual variations in observed SCN space were found to be high (the mean square of individual differences was 2.9466) these changes were not significant, but, if the series had been larger, a significant difference, even though small, might have emerged. The evidence, therefore, from this group did 
not suggest that the SCN space had diminished significantly during this period of restricted refeeding.

Because the characteristic feature of the first type of oedema is the constancy of the plasma volume and a slight expansion of the SCN space in spite of severe loss of bodyweight, we propose the use of the term 'isohydric famine oedema' for such cases. The second type of oedema characterized by a fall in plasma-protein concentration below the critical level may be called 'hypoproteinaemic famine oedema'. We admit that the isohydric type may grade insensibly into the hypoproteinaemic type, and that the oedema fluid of the latter type will consist of the normal volume of extracellular fluid plus excess fluid accumulating as the result of the disturbed osmotic pressure relationships.

In famine oedema of the hypoproteinaemic type it is conceivable that the capillary wall may become more permeable to protein and allow protein to escape into the extracellular fluid compartment with a consequent accumulation of fluid in the compartment. We were able to collect large samples of uncontaminated oedema fluid from our single case of massive oedema (patient F.). Analysis of these samples showed that the total proteins varied between 0.45 and $0.68 \mathrm{~g} . / 100 \mathrm{ml}$. The albumin fraction varied between 0.25 and $0.43 \mathrm{~g} . / 100 \mathrm{ml}$. The total concentrations may be compared with those found by Drinker \& Field (1933) for lymph from the skin of the human leg which were $0.69 \mathrm{~g} . / 100 \mathrm{ml}$. at rest and $0.49 \mathrm{~g} . / 100 \mathrm{ml}$. when standing or walking. If the volume of the 'SCN oedema fluid' (see below) in patient $\mathrm{F}$. is estimated as 351 ., the total excess protein in the extracellular space would thus range between 157.5 and $239 \mathrm{~g}$. The possibility of an increased permeability of the capillary wall to protein cannot therefore be excluded.

Our data showed that in isohydric oedema in some subjects of the German group traces of oedema were present at the 28 th day of observation under basal conditions and became marked in the late afternoon. The question might be asked: At what time in the process of tissue wasting under restricted food intake does oedema become obvious? Henschel et al. (1947) estimated the 'thiocyanate (SCN) oedema fluid', which they defined as the difference between the fluid estimated as $23.5 \%$ of the observed body-weight and that actually determined. This SCN oedema fluid averaged $10.48 \%$ of the body-weight in their series at the end of the starvation period. Only in those men whose $\mathrm{SCN}$ oedema fluid exceeded $10 \%$ of the body-weight could clinical oedema be recognized. Calculating this SCN oedema fluid in our subjects at the 28th day, we found that it averaged 5.561 . and represented $10.7 \%$ of the body-weight. For those subjects who at this time showed evidence of oedema the SCN oedema fluid averaged 5.951 . or I $14 \%$ of the body-weight. These values would appear to represent the critical level for the appearance of oedema.

We think that isohydric famine oedema appears because of the maintenance of constant vascular, and slightly increased extracellular, fluid volumes with decreasing tissue weight. Wasting of tissues permits up to about 51 . of fluid to be held in excess of the normal proportion $(23.5 \%$ ) of vascular and extracellular fluid in the body-weight without the appearance of oedema. We have no clue as to the mechanism which maintains the absolute volume of the plasma and SCN space within narrow limits 
while tissue wasting progresses. Henschel et al. (1947) have asked the question: 'What mechanism is there which would operate to cause the fluid mass of the body to shrink in proportion to the cellular elements?' To this we have no answer. On the other hand, we deem it significant that in isohydric oedema the giving of a diet, which was in excess of $35 \mathrm{Cal}$. and $0.17 \mathrm{~g}$. protein N/ $\mathrm{kg}$. body-weight/day, brought about a decrease in weight which began within $24 \mathrm{hr}$. of the start of the new diet and lasted until between 2 and $7 \mathrm{~kg}$. body-weight had been lost. This loss in weight was related to an increased urine output. Why should this weight loss have ceased when the fluid lost was about equal to the SCN oedema fluid, or in other words when the SCN space had become adjusted to about its normal relative level of $23.5 \%$ of the body weight?

In our study of the effect of increased food intake on oxygen consumption in emaciated people we found that such intake brought about a rise in oxygen consumption which was proportional to the calorie intake/kg. body-weight/day (Beattie \& Herbert, 1947). With such an increase in metabolism we can visualize an increased minute cardiac output and presumably an increase in blood flow through the kidney. This may have the effect of producing an increased urinary flow, but the nature of the mechanism which later brings this increased urinary flow down to a normal level, and so causes stabilization of weight followed by a slow weight increase as protein and fat reserves are built up, is not yet known.

The absence of this immediate effect in body-weight and urinary flow in cases of hypoproteinaemic famine oedema demands an explanation. There is no doubt, as we have observed, that the increased food intake causes a rise in oxygen consumption and presumably a rise in cardiac output. An increased kidney blood flow cannot be denied in these cases and is admitted as a possibility in isohydric oedema cases. Yet, for a variable period of days, no diuretic effect was seen. Then, without warning, and without change in plasma-protein concentration, a vigorous diuresis appeared and the body-weight fell.

This latter type of oedema has, therefore, two distinctive metabolic features. First is the apparent inability of the organism to maintain the plasma-protein concentration, although in comparable cases of isohydric oedema with the same degree of weight loss the plasma-protein level is maintained. Does this failure betoken the operation of a hormonal mechanism which inhibits protein synthesis? The second feature we have just described. Does the time lag between increased calorie and protein intake and diuresis indicate the lack of some substance necessary for full renal function which is supplied only slowly after refeeding begins and which produces its effect when a threshold value is attained? Until we have thrown some light on these fundamental questions we cannot be said to have solved the problem of famine oedema of both types.

It appears that if nutritional oedema is divided into two types the many divergent records and conclusions in the literature become explicable. For example, Youmans, Wells, Donley, Miller \& Frank (r934) reported total plasma-protein concentrations in cases of nutritional oedema which were comparable with our examples of isohydric famine oedema. They include in their records two patients who showed total plasma 
proteins below the Weech \& Ling (1931) critical level. We would classify these two cases as hypoproteinaemic famine oedema. These workers demonstrated the importance of posture and tissue pressure in the production and maintenance of oedema. They came to the conclusion that the increase in tissue pressure as oedema increased acted as a limiting factor in preventing loss of fluid from the blood to the tissue spaces. This may be true in cases of isohydric famine oedema, but it cannot be true in the oedema of hypoproteinaemia. Tissue pressures in our case of massive famine oedema were not effective in preventing the patient from retaining in his tissues an amount of oedema fluid which was not less than 351.

Henschel et al. (1947) have quoted many other observers who recorded the presence of oedema without significant alterations in the plasma-protein levels.

\section{SUMMARY}

1. Observation on famished subjects indicated that, when the body-weight showed a steady loss on a low constant intake of food, and the appearance of oedema did not produce any change in the rate of fall, the plasma-protein concentration at the end of the period of low food intake was within the limits of normal or was only slightly reduced.

2. When the appearance of oedema brought about an increase in body-weight on a low food intake, the concentration of plasma proteins was less than $5 \mathrm{~g} / 100 \mathrm{ml}$.

3. Cases of the first type of oedema, when given a high-calorie diet, showed an immediate fall in body-weight without any change in plasma-protein concentration.

4. Cases of the second type of oedema (i.e. with hypoproteinaemia) failed to show this immediate response.

5. The division of nutritional oedema into two types (a) without hypoproteinaemia and $(b)$ with hypoproteinaemia is suggested.

6. Investigation of oedema of the first type demonstrated that the absolute plasma volume had remained at its normal pre-starvation level irrespective of the degree of weight loss. The thiocyanate-space volume (SCN space) was only slightly increased above the normal pre-starvation value. Because of the constancy of these two fluid volumes, oedema in such cases may be called 'isohydric famine oedema'.

7. Oedema appeared in such patients when the amount of SCN space fluid exceeded the amount calculated as $23.5 \%$ of the observed body-weight by about 51 . or around $10 \%$ of the body-weight.

8. In one case of massive hypoproteinaemic famine oedema the protein content of the oedema fluid was normal for tissue fluid. The permeability of the capillaries to plasma proteins may, however, have increased. The excess oedema fluid of this patient was calculated at approx. $35 \mathrm{l}$. In him the SCN space was obviously much enlarged. This may be characteristic of hypoproteinaemic famine oedema.

We are indebted to Dr Ancel Keys and his colleagues for putting at our disposal their data on plasma and thiocyanate-space volumes prior to their publication and for their many helpful suggestions when we discussed our data with them. We wish to 
thank Dr John F. Loutit, who made the plasma-volume determinations on our Dutch patients, and Squadron-Leader F. W. Ford, M.B., who assisted us with the plasmavolume and thiocyanate-space determinations in our German subjects. Our thanks are due to our technical staff in Holland and Germany for their painstaking work. We are greatly indebted to Dr K. Mather for advising us on the statistical treatment of our data. The Royal College of Surgeons of England released two of us (J. B. and P. H. H.) to carry out this investigation and permitted us to take necessary equipment and stores to the Continent. The University of Cambridge released one of us (D. J. B.) to take part in the German phase. The expenses of the investigation were borne by the Medical Research Council.

\section{REFERENCES}

Beattie, J. \& Herbert, P. H. (1947). Brit. F. Nutrit. I, 192.

Beattie, J., Herbert, P. H. \& Bell, D. J. (1947). Brit. Y. Nutrit. I, 202.

Bowler, R. G. (1944). Biochem. F. 38, 385 .

Drinker, C. K. \& Field, M. E. (1933). Lymphatics, Lymph and Tissue Fluid, p. 69. Baltimore: Williams and Wilkins Co.

Gibson, J. G. J. \& Evans, W. A. J. (1937). J. clin. Invest. 16, 301.

Gibson, J. G. J. \& Evelyn, K. A. (1938). Y. clin. Inoest. 17, 153.

Greenberg, D. M. (1929). Y. biol. Chem. 82, 545.

Henschel, A., Mickelsen, O., Taylor, H. L. \& Keys, A. (1947). Amer. F. Physiol. 150, 170.

Jacobsen, C. F. \& Linderstrom-Lang, K. (1940). Acta physiol. scand. 1, 149.

Phillips, R. A., Van Slyke, D. D., Dole, V. P., Emerson, K., Jr., Hamilton, P. B. \& Archibald, R. M. (1945). Copper Sulfate Method for Mearuring Specific Gravities of Whole Blood and Plasma. New York: Josiah Macy Jr. Foundation.

Rutstein, D. D., Thomson, K. J., Tolmach, D. M., Walker, W. H. \& Floody, R. J. (1945). f. clin. Invest. 24, 11.

Weech, A. A. \& Ling, S. M. (1931). F. clin. Invest. ro, 869.

Youmans, J. B., Wells, H., Donley, D., Miller, D. \& Frank. H. (1934). J. clin. Invest. I3, 447. 